\title{
Improved HPLC Method for Determination of Four PPIs, Omeprazole, Pantoprazole, Lansoprazole and Rabeprazole in Human Plasma
}

\author{
Maryam Noubarani, Fariborz Keyhanfar, Manijeh Motevalian, Masoud Mahmoudian \\ Department of Pharmacology, Faculty of Medicine, Iran University of Medical Sciences, Tehran, Iran \\ Received, November 21, 2009; Revised, December 22, 2009; Accepted, January 14, 2010; Published, January 18, 2010.
}

\begin{abstract}
PURP OSE: To develop a simple and rapid HPLC method for measuring of four proton-pump inhibitors (PPIs), omeprazole (OPZ), pantoprazole (PPZ), lansoprazole (LPZ) and rabeprazole (RPZ) concentrations in human plasma. METHODS: Following a single step liquid-liquid extraction analytes along with an internal standard (IS) were separated using an isocratic mobile phase of phosphate buffer (10 $\mathrm{mM}$ )/acetonitrile (53/47, v/v adjusted $\mathrm{pH}$ to 7.3 with triethylamine) at flow rate of $1 \mathrm{~mL} / \mathrm{min}$ on reverse phase TRACER EXCEL 120 ODS-A column at room temperature. RESULTS: Total analytical run time for selected PPIs was $10 \mathrm{~min}$. The assays exhibited good linearity $\left(\mathrm{r}^{2}>0.99\right)$ over the studied range of 20 to $2500 \mathrm{ng} / \mathrm{mL}$ for OPZ, 20 to $4000 \mathrm{ng} / \mathrm{mL}$ for PPZ, 20 to $3000 \mathrm{ng} / \mathrm{mL}$ for LPZ and 20 to $1500 \mathrm{ng} / \mathrm{mL}$ for RPZ. The recovery of method was equal or greater than $80 \%$ and lower limit of quantification (LLOQ) was $20 \mathrm{ng} / \mathrm{mL}$ for four PPIs. Coefficient of variation and error at all of the intra-day and inter-day assessment were less than 9.2\% for all compounds. CONCLUSIONS: The results indicated that this method is a simple, rapid, precise and accurate assay for determination of four PPIs concentrations in human plasma. This validated method is sensitive and reproducible enough to be used in pharmacokinetic studies and also is time- and cost-benefit when selected PPIs are desired to be analyzed.
\end{abstract}

\section{INTRODUCTION}

Proton pump inhibitors (PPIs) are among the most extensively used drugs in the world. As a therapeutic group, the PPIs are highly useful for the relief of symptoms and healing of gastro esophageal reflux disease, peptic ulcer, Helicobacter pylori infection, prevention and treatment of nonsteroidal anti-inflammatory drugs (NSAIDs)-induced gastrointestinal lesions (complications) and management of hypersecretory states such as Zollinger-Ellison syndrome. Following oral administrations they are absorbed in the small intestine and reach via systemic circulation, to gastric parietal cells, where they bind to proton pump $\left(\mathrm{H}^{+} / \mathrm{K}^{+}\right.$ATPase $)$and disturb the function of proton pump, thereby resulting in a potent acid inhibition (1).

CYP2C19 is responsible for $>80 \%$ of the metabolism of omeprazole (OPZ), pantoprazole (PPZ) and lansoprazole (LPZ), with CYP3A4 undertaking most of the remaining metabolism. Rabeprazole (RPZ) may have less reliance on
CYP2C19 as it undergoes nonenzymatic conversion to RPZ thioether. Polymorphism of CYP2C19 influences pharmacokinetics and pharmacodynamics of PPIs (2).

A review of the literature revealed that several high performance liquid chromatographic (HPLC) methods have been used for determination of PPIs alone or with their metabolites in human plasma and urine (3-28).

Hishinuma et al. reported a LC/MS/MS method for determination of LPZ and RPZ in human plasma (29). Although this method meets many or all generally accepted criteria for validated analysis of two PPIs, it involves costly equipment that is not available in many laboratories.

The PPI pharmacophore is 2pyridylmethylsulfinylbenzimidazole (Figure 1). Four PPI products currently in the market (OPZ,

Corresponding Au thor: Dr. Fariborz Keyhanfar, Department of Pharmacology, Faculty of Medicine, Iran University of Medical Sciences, Tehran, Iran, E-mail: fkeyhanfar@iums.ac.ir 
PPZ, LPZ and RPZ) all contain this basic structural framework and differ only in the nature of substituents placed on the pyridine and benzimidazole rings (30). The practice of personalized medicine is now regarded as important in the prescription of medication. Therefore, it is necessary to understand the individual differences of the curative effect of PPIs in order to promote individualized medical care. Development of rapid and simple methods of quantification, applicable and validated for related drugs in a wide range of concentrations, also using available internal standard (IS) and simple operations in quantification of drug concentrations will be timeand cost-benefit.

In this paper we describe a rapid and simple HPLC method for determination of OPZ, PPZ, LPZ and RPZ in human plasma using ultraviolet detection that allows rapid processing of large number of plasma samples. The method employed a mobile phase of $\mathrm{pH} 7.3$, permitting the stability of PPIs and use of TRACER EXEL 120 ODS-A column, much less expensive than alkaline-resistant polymer-coated column. PPIs were also used as IS for other PPIs assay in our method. The assay method was validated according to FDA guidelines (31).

\section{MATERIALS AND METHODS}

\section{Chemicals}

HPLC grade acetonitrile and methanol (Darmstadt, Germany) were used for the HPLC analysis. Deionized water was used from a Milli-Q system (Millipore, Bedford, MA, USA). Potassium dihydrogen phosphate, tert-butyl methyl ether and triethylamine were purchased from Merck (Darmstadt, Germany). OPZ, PPZ, LPZ and RPZ were obtained from Hetero Drugs Limited (Erragadda, Heydarabad, India) and their purity was over $99 \%$ by HPLC analysis. All other chemicals were of analytical grade.

\section{Apparatus and chromatographic conditions}

The HPLC system (Waters chromatography division, Milford, MA, USA) consisted of a model 600 pump, a 486 UV tunable absorbance detector, a 7725 i Rheodyne manual injector, a model 764 data module. Chromatographic separation of PPIs was achieved using a TRACER EXCEL 120 ODS-A (5 $\mu \mathrm{m} 250 \mathrm{~mm} \times 4.6 \mathrm{~mm}$ i.d, Teknokroma) reverse phase analytical column with a $\mu$ Bondapak $^{\mathrm{TM}} \mathrm{C}_{18}$ Guard column (5 $\mu \mathrm{m}, 120 \mathrm{~A}^{\mathrm{o}}$, Ireland). The mobile phase consisting of a mixture of phosphate buffer $(10 \mathrm{mM}) /$ acetonitrile $(53 / 47, \mathrm{v} / \mathrm{v}$ adjusted $\mathrm{pH}$ to 7.3 with triethylamine). The mobile phase was pumped at an isocratic flow rate of $1 \mathrm{~mL} / \mathrm{min}$ at room temperature. The wavelength of UV detection was set at 302, 290, 285 and $284 \mathrm{~nm}$ for OPZ, PPZ, LPZ and RPZ assay, respectively.

\section{Preparation of standard solutions}

A stock solution $(1 \mathrm{mg} / \mathrm{mL})$ of OPZ, PPZ, LPZ and RPZ was prepared by dissolving $5 \mathrm{mg}$ of drugs in $5 \mathrm{~mL}$ of mobile phase. Working solutions were prepared from the stock solution by sequential dilution with mobile phase just before use. All solutions were protected from light by covering them with aluminum foil and stored in darkness at $20^{\circ} \mathrm{C}$. In the case of OPZ and LPZ assays, PPZ was used as IS and in PPZ and RPZ assays, LPZ was used as IS.

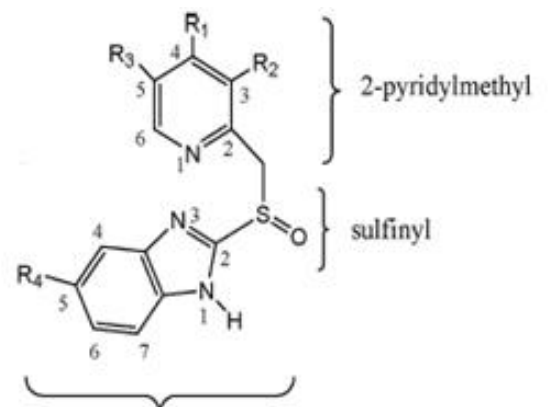

\begin{tabular}{lcccc} 
Compound & $\mathrm{R}_{1}$ & $\mathrm{R}_{2}$ & $\mathrm{R}_{3}$ & $\mathrm{R}_{4}$ \\
\hline Omeprazole & $\mathrm{OCH}_{3}$ & $\mathrm{CH}_{3}$ & $\mathrm{CH}_{3}$ & $\mathrm{OCH}_{3}$ \\
Pantoprazole & $\mathrm{OCH}_{3}$ & $\mathrm{OCH}_{3}$ & $\mathrm{H}$ & $\mathrm{OCHF}_{2}$ \\
Lansoprazole & $\mathrm{OCH}_{2} \mathrm{CF}_{3}$ & $\mathrm{CH}_{3}$ & $\mathrm{H}$ & $\mathrm{H}$ \\
Rabeprazole & $\mathrm{O}(\mathrm{CH} 2) 3 \mathrm{CH}_{3}$ & $\mathrm{CH}_{3}$ & $\mathrm{H}$ & $\mathrm{H}$
\end{tabular}

benzimidazole

Figure 1. Chemical structures of selected PPIs 


\section{Extraction procedure}

Plasma samples $(1 \mathrm{~mL})$ were transferred to a $15-\mathrm{mL}$ glass tube, and then $50 \mu \mathrm{L}$ of IS working solution $(10 \mu \mathrm{g} / \mathrm{mL})$ was spiked. $4-\mathrm{mL}$ aliquot of extraction solvent, tert-butyl methyl ether, was added. The sample was vortexed for $3 \mathrm{~min}$. The sample was then centrifuged for $3 \mathrm{~min}$ at $3000 \mathrm{rpm}$. The organic layer $(3 \mathrm{~mL})$ was quantitatively transferred to a $6-$ $\mathrm{mL}$ glass tube and evaporated at $37^{\circ} \mathrm{C}$ under a stream of nitrogen. Then, the dried extract was reconstituted with $200 \mu \mathrm{L}$ of mobile phase and a 50 $\mu \mathrm{L}$ aliquot was injected into chromatographic system.

\section{Extraction efficacy}

Recovery of each analyte was determined by comparing the peak area of the analyte extracted from the plasma with peak area obtained by the direct injection of pure standard analyte in mobile phase at three different concentrations containing low, middle and high concentration of four PPIs separately.

\section{Calibration samples}

To $950 \mu \mathrm{L}$ of blank human plasma, $50 \mu \mathrm{L}$ of working standard of OPZ, PPZ, LPZ or RPZ was added, yielding final concentrations of 20-2500 $\mathrm{ng} / \mathrm{mL}$ OPZ, 20-4000 ng/mL PPZ, 20-3000 ng/mL LPZ and $20-1500 \mathrm{ng} / \mathrm{mL}$ RPZ. To this mixture, 50 $\mu \mathrm{L}$ of IS working solution was added to yield IS concentration of $500 \mathrm{ng} / \mathrm{mL}$. Calibration samples were prepared for analysis as described above. Each calibration curve was analyzed three times with at least six different concentrations using the same HPLC conditions as described above. The peak area ratios of drugs to the IS for each of the standard solutions were calculated and plotted as a function of drug concentrations in human plasma. The calibration curves were acceptable only if they had correlation coefficients $\left(\mathrm{r}^{2}\right)$ of 0.99 or greater. The acceptance criterion for each back-calculated standard concentration was $15 \%$ deviation from the nominal value except for the lower limit of quantification (LLOQ), which was set at 20\% (31).

\section{Precision and accuracy}

To examine the accuracy and precision of our method, plasma spiked with four concentrations consisting of lower limit of quantification, low, middle and high concentrations of each analyte, were prepared. Intra-day precision and accuracy were evaluated by analyzing the spiked controls five times a day. This was repeated on three separate days to permit an assessment of inter-day accuracy and precision. Precision was evaluated at each concentration by comparing the values for the coefficient of variation: $\mathrm{CV} \%=(\mathrm{SD} /$ mean measured concentration) $\times 100$ and accuracy of the assay was determined in terms of \% error by dividing the measured concentration minus the expected concentration to the expected concentration $\times 100$.

\section{Stability}

Stability of plasma quality control (QC) samples of OPZ, PPZ, LPZ and RPZ were subjected to shortterm room temperature, was examined by keeping replicates of plasma quality control samples for 12 h. Freeze-thaw stability of each analyte in human plasma samples were obtained over three freezethaw cycles, by thawing at room temperature for 2$3 \mathrm{~h}$, refrozen for 12-24 h. Stability of drugs in human plasma was tested after storage at below $80^{\circ} \mathrm{C}$ for 3 months. The stability of standard solutions was also tested at room temperature for 2$12 \mathrm{~h}$ and upon refrigeration $\left(-20^{\circ} \mathrm{C}\right)$ for 14 days. In all stability studies two quality control concentrations were used, $60 \mathrm{ng} / \mathrm{mL}$ as low quality control (LQC) for each analyte and $2200 \mathrm{ng} / \mathrm{mL}$ OPZ, $3500 \mathrm{ng} / \mathrm{mL}$ PPZ, $2500 \mathrm{ng} / \mathrm{mL} \mathrm{LPZ}$ and 1200 $\mathrm{ng} / \mathrm{mL} \mathrm{RPZ}$ as high quality control (HQC). For each concentration and each storage condition, six replicates were analyzed. The concentration of OPZ, PPZ, LPZ and RPZ after each storage period was related to the initial concentration as determined for the samples that were freshly prepared and processed immediately. Samples were considered stable if the assay values were within the acceptable limits of accuracy and precision (31).

\section{Application to pharmacokinetic study}

In order to test for utility of the described method in human pharmacokinetic studies, OPZ, PPZ, LPZ and RPZ were administered as a single oral dose in male subjects. A total of 30 subjects aged 20-45 years, weighted $54-83 \mathrm{~kg}$ enrolled in the study. All the subjects were healthy and none were taking any medication. The ethics committee approved the protocol and volunteers have signed informed consent. The plasma samples were collected up to $12 \mathrm{~h}$ after a single oral dose of $20 \mathrm{mg}$ OPZ (Losec), 20 mg PPZ (Pantozol), $30 \mathrm{mg}$ LPZ (Zoton 
FasTab $^{\circledR}$ ) and $20 \mathrm{mg}$ RPZ (Rabekind-Fast). Blood samples were collected in heparinized tubes and centrifuged for $15 \mathrm{~min}$ at $3000 \mathrm{rpm}$ and the plasma was separated and stored at $-80^{\circ} \mathrm{C}$ until analysis. $1 \mathrm{~mL}$ plasma sample was spiked with $50 \mu \mathrm{L}$ IS and processed as mentioned in the extraction procedure section.

\section{RESULTS}

Preliminary experiments were carried out to optimize the experimental parameters affecting chromatographic separation of OPZ, PPZ, LPZ and RPZ. To obtain chromatograms with good separation various columns, mixtures of mobile phase and different flow rates were investigated. For the assay of PPIs in human plasma a ODS-A $\mathrm{C}_{18}$ was found to be better than Nova-Pak $\mathrm{C}_{18}$ or inertsil ODS-3V $\mathrm{C}_{18}$. Various mixtures of phosphate buffer/acetonitrile were used as mobile phase and results indicated that phosphate buffer (10 $\mathrm{mM})$ /acetonitrile (53/47, adjusted $\mathrm{pH}$ to 7.3 with triethylamine) gives the best resolution. Also using different flow rates (in the range of $0.8-2 \mathrm{~mL} / \mathrm{min}$ ) revealed that the best separation was achieved on a flow rate of $1.00 \mathrm{~mL} / \mathrm{min}$ of mobile phase. OPZ, RPZ, PPZ and LPZ were well separated with retention times of 5.7, 5.9, 6.4 and $8.1 \mathrm{~min}$, respectively. Figure 2, 3, 4 and 5 show an overlay chromatograms for the blank human plasma (free of analyte and IS), human plasma spiked with IS, human plasma spiked with IS and OPZ, PPZ, LPZ or RPZ at their respective LLOQ $(20 \mathrm{ng} / \mathrm{mL}$ concentration) and plasma sample obtained from a healthy subject after $3 \mathrm{~h}$ following oral administration of $20 \mathrm{mg}$ OPZ, $20 \mathrm{mg}$ PPZ, $30 \mathrm{mg}$ LPZ and $20 \mathrm{mg}$ RPZ. No interfering peaks from endogenous compounds are observed at the retention times of analytes.

Linearity, precision and accuracy were determined to assess the performance of method. Linear calibration curves were constructed for each analyte. The correlation coefficients and equations for the calibration curves are shown in Table 1. Highly linear relationship between peak area ratios and human plasma concentration of drugs were evident over the broad concentration ranges studied (Table 1).
The LLOQ as the lowest concentration on the calibration yielding acceptable precision $(\mathrm{CV} \leq 20 \%)$ and accuracy (80-120\%) of theoretical value for four PPIs was $20 \mathrm{ng} / \mathrm{mL}$ (31). Table 2 shows the intra-day and inter-day assay validation quality report. Coefficient of variation and error at all of the intraday and inter-day assessment were less than $9.2 \%$.

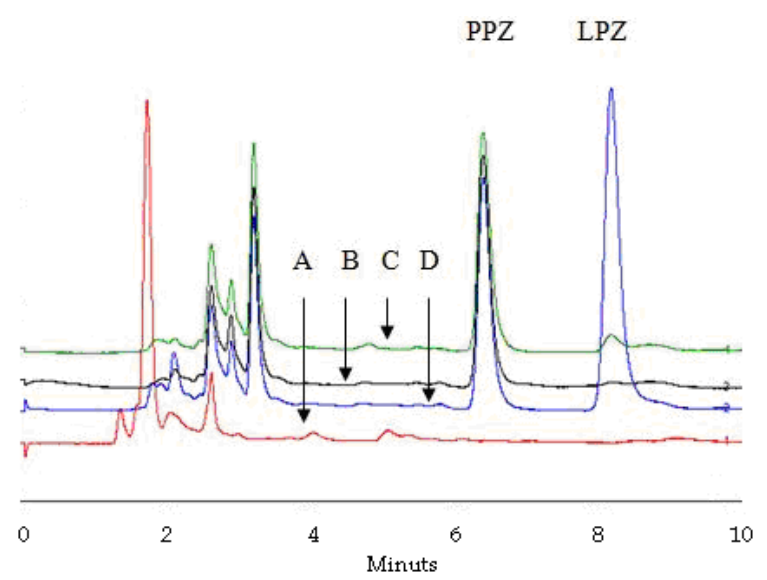

Figure 2. Overlay chromatograms of (A) blank human plasma, (B) human plasma spiked with IS $(500 \mathrm{ng} / \mathrm{mL})$, (C) human plasma spiked with IS and OPZ at LLOQ, (D) plasma sample from a healthy subject following a $20 \mathrm{mg}$ oral dose of OPZ.

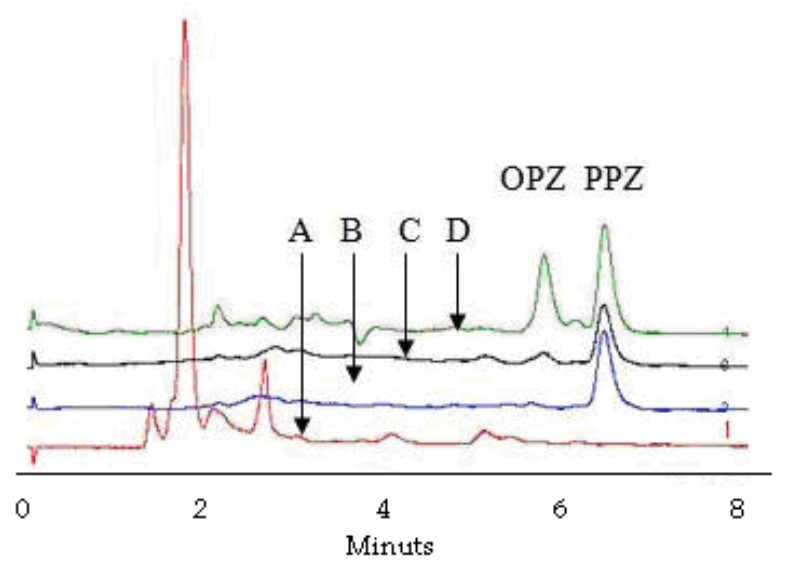

Figure 3. Overlay chromatograms of (A) blank human plasma, (B) human plasma spiked with IS $(500 \mathrm{ng} / \mathrm{mL})$, (C) human plasma spiked with IS and PPZ at LLOQ, (D) plasma sample from a healthy subject following a $20 \mathrm{mg}$ oral dose of PPZ.

Various organic solvents such as diethyl ether, methylene chloride, ethyl acetate, tert-butyl 
Table 1. Linear ranges and correlation coefficients of calibration curves.

\begin{tabular}{ccccc}
\hline Analyte & Retention time $(\mathrm{min})$ & Range of conc. $(\mathrm{ng} / \mathrm{mL})$ & Equation & $\mathrm{r}^{2}$ \\
\hline OPZ & 5.7 & $20-2500$ & $\mathrm{Y}=0.0071 \mathrm{x}-0.0056$ & 0.999 \\
RPZ & 5.9 & $20-1500$ & $\mathrm{Y}=0.0014 \mathrm{x}+0.0072$ & 0.996 \\
PPZ & 6.4 & $20-4000$ & $\mathrm{Y}=0.0017 \mathrm{x}-0.001$ & 0.999 \\
LPZ & 8.1 & $20-3000$ & $\mathrm{Y}=0.0027 \mathrm{x}+0.033$ & 0.998 \\
\hline$Y$ and $X$ are the peak area ratios and analyte concentration $(\mathrm{ng} / \mathrm{mL})$ in a sample, respectively & \\
\hline
\end{tabular}

methyl ether and dichloromethane alone or in combination were tested. The best solvent was found to be tert-butyl methyl ether, which allowed extraction of four PPIs in high yield. The recoveries of four PPIs were more than $80 \%$ (Table 3 ) and the dependence on concentration was negligible.

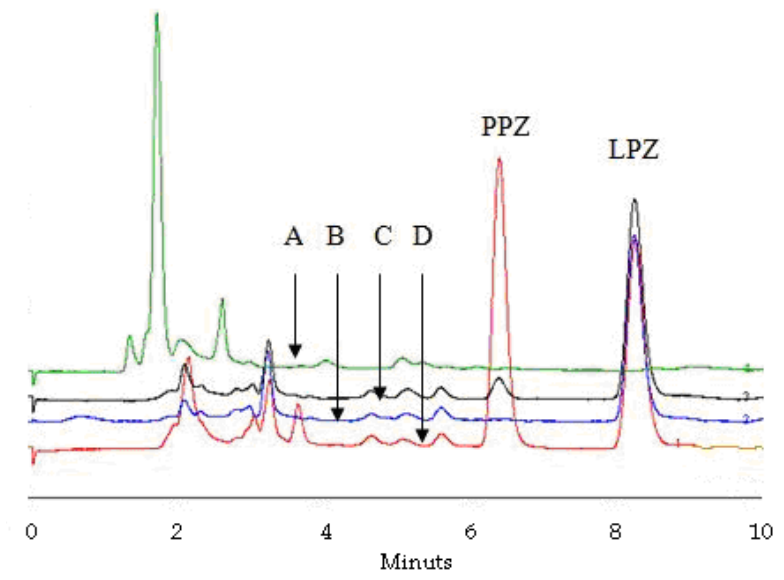

Figure 4. Overlay chromatograms of (A) blank human plasma, (B) human plasma spiked with IS (500 ng/mL), (C) Human plasma spiked with IS and LPZ at LLOQ, (D) plasma sample from a healthy subject following a $30 \mathrm{mg}$ oral dose of LPZ.

The stability experiments were aimed at testing all possible conditions that the samples might experience after collecting and prior the analysis. Acceptable analyte stability was demonstrated for all phases of storage and processing. All stability results are summarized in Table 4. Three freeze-thaw cycles and $12 \mathrm{~h}$ room temperature storage for low and high quality control samples indicated that OPZ, PPZ, LPZ and RPZ were stable in human plasma under these conditions. Quality control samples were stable for at least 3 months if stored frozen at below $-80^{\circ} \mathrm{C}$.

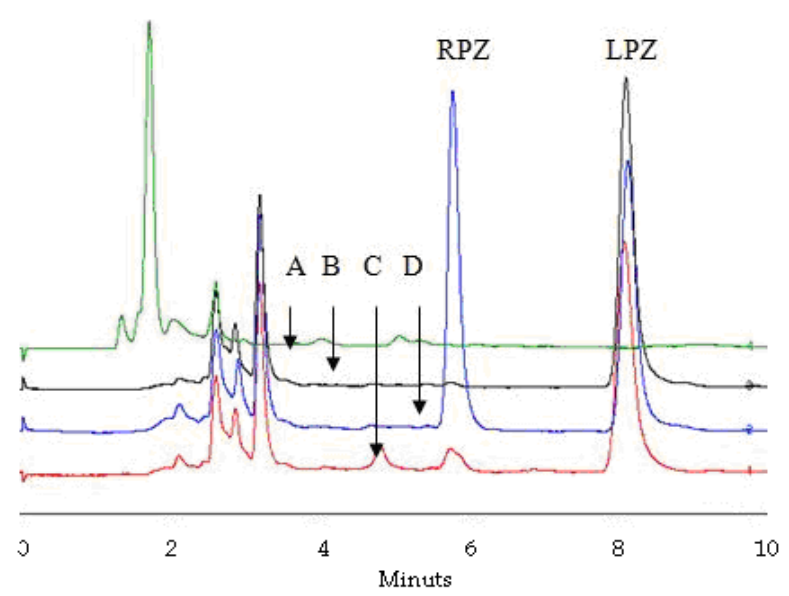

Figure 5. Overlay chromatograms of (A) blank human plasma, (B) human plasma spiked with IS (500 ng/mL), (C) Human plasma spiked with IS and RPZ at LLOQ, (D) plasma sample from a healthy subject following a $20 \mathrm{mg}$ oral dose of RPZ.

In addition, the stability of processed plasma sample was also tested. It was found that four PPIs were stable at room temperature for $12 \mathrm{~h}$ and at $-20^{\circ} \mathrm{C}$ for $72 \mathrm{~h}$. The standard solutions of OPZ, PPZ, LPZ and RPZ in mobile phase allowed standing at room temperature $12 \mathrm{~h}$ and at $-20^{\circ} \mathrm{C}$ for 14 days. Mean serum concentration-time profiles OPZ, PPZ, LPZ and RPZ are shown in Figure 6 and pharmacokinetic parameters are summarized in Table 5.

\section{DISCUSSION}

Previous published methods focused only on analyzing one PPI. Our current method describes a basic assay method can be used to assay four PPIs when given separately. According to literature in many HPLC methods reported for determination of 
Table 2: Precision and accuracy of OPZ, PPZ, LPZ and RPZ determination in human plasma.

\begin{tabular}{|c|c|c|c|c|c|c|}
\hline \multirow[b]{2}{*}{$\begin{array}{l}\text { Analytes } \\
(\mathrm{ng} / \mathrm{mL})\end{array}$} & \multicolumn{3}{|c|}{ Intra-day $(n=5)$} & \multicolumn{3}{|c|}{ Inter-day $(\mathrm{n}=5)$} \\
\hline & Mean \pm S.D. & $\mathrm{CV} \%$ & error $\%$ & Mean \pm S.D. & $\mathrm{CV} \%$ & error $\%$ \\
\hline \multicolumn{7}{|l|}{ OPZ } \\
\hline 20 & $20.0 \pm 1.6$ & 8.09 & 0.15 & $19.1 \pm 1.7$ & 8.90 & -4.50 \\
\hline 60 & $55.2 \pm 3.5$ & 6.34 & -8.00 & $57.7 \pm 2.9$ & 5.03 & -3.83 \\
\hline 1200 & $1091 \pm 9$ & 0.82 & -9.08 & $1091 \pm 29$ & 2.66 & -9.08 \\
\hline 2200 & $2335 \pm 99$ & 4.24 & 6.14 & $2270 \pm 74$ & 3.26 & 3.18 \\
\hline \multicolumn{7}{|l|}{ PPZ } \\
\hline 20 & $20.9 \pm 0.8$ & 3.83 & 4.50 & $21.1 \pm 1.3$ & 6.16 & 5.50 \\
\hline 60 & $58.4 \pm 4.2$ & 7.19 & -2.67 & $59.0 \pm 3.1$ & 5.29 & -1.73 \\
\hline 2000 & $1910 \pm 22$ & 1.15 & -4.50 & $1853 \pm 63$ & 3.40 & -7.35 \\
\hline 3500 & $3602 \pm 50$ & 1.39 & 2.91 & $3289 \pm 68$ & 2.07 & -6.03 \\
\hline \multicolumn{7}{|l|}{ LPZ } \\
\hline 20 & $21.1 \pm 1.4$ & 6.63 & 5.50 & $20.3 \pm 1.3$ & 6.51 & 1.50 \\
\hline 60 & $62.1 \pm 1.9$ & 3.06 & 3.50 & $63.1 \pm 2.9$ & 4.51 & 5.17 \\
\hline 1500 & $1489 \pm 41$ & 2.75 & -0.73 & $1524 \pm 42$ & 2.75 & 1.60 \\
\hline 2500 & $2351 \pm 89$ & 3.79 & -5.96 & $2688 \pm 52$ & 1.91 & 7.52 \\
\hline \multicolumn{7}{|l|}{ RPZ } \\
\hline 20 & $19.9 \pm 1.8$ & 9.05 & -0.50 & $19.8 \pm 1.8$ & 9.09 & -1.00 \\
\hline 60 & $61.4 \pm 3.3$ & 5.37 & 2.33 & $61.9 \pm 3.6$ & 5.82 & 3.17 \\
\hline 700 & $721 \pm 15$ & 2.08 & 3.00 & $724 \pm 15$ & 2.07 & 3.43 \\
\hline 1200 & $1229 \pm 60$ & 4.88 & 2.42 & $1219 \pm 54$ & 4.43 & 1.58 \\
\hline
\end{tabular}

OPZ, PPZ, LPZ and RPZ the chromatographic run time was between 8 and $25 \min (3-9,12-17)$ or $\geq 30$ $\min (10,11)$ for $\mathrm{OPZ},>10 \mathrm{~min}$ for $\operatorname{RPZ}(24,26)$ and $11 \mathrm{~min}$ for $\operatorname{LPZ}(19,21,22)$. Uno et al. reported a simple and sensitive column-switching HPLC method for determination of LPZ and LPZ metabolites in plasma using liquid-liquid extraction but retention time was 19 min (28). In LC method for the determination of PPZ reported by Ramakrishna et al. retention time was 6.8 min but separation was done at $30^{\circ} \mathrm{C}$ and relatively low recovery $(48.7 \%)$ was observed (23). In our method retention times were less than $9 \mathrm{~min}$ for all compounds. The shorter run time allows for more samples to be analyzed per day.

Due to poor stability of PPIs under acidic conditions, previous methods have performed chromatographic separation at $\mathrm{pH}$ of 7.0 or greater $(3,6,8,9,26)$. Kobayashi et al. have reported a simple method for OPZ and its metabolites determination with a more expensive alkalineresistant column (6). Mihaly et al. reported a procedure using a mobile phase with $\mathrm{pH}$ of 7 , but the method was not validated for its accuracy, while the precision was carried out using a single high concentration value of $104.7 \mathrm{ng} / \mathrm{mL}(9)$.

Table 3. Recoveries of OPZ, PPZ, LPZ and RPZ ( $\mathrm{n}=6)$.

\begin{tabular}{lcccc}
\hline Concentration $(\mathrm{ng} / \mathrm{mL})$ & OPZ PPZ & LPZ & RPZ \\
\hline LQC $^{*}$ & $84.5 \pm 1.1$ & $86.8 \pm 1.0$ & $83.3 \pm 4.1$ & $80.2 \pm 1.1$ \\
MQC $^{* *}$ & $82.3 \pm 3.0$ & $88.8 \pm 2.0$ & $80.9 \pm 0.7$ & $82.8 \pm 1.0$ \\
HQC*** & $84.2 \pm 1.0$ & $85.4 \pm 3.9$ & $84.8 \pm 1.1$ & $81.6 \pm 3.0$ \\
\hline *LQC is $60 \mathrm{ng} / \mathrm{mL}$ for each analyte, ${ }^{* *} \mathrm{MQC}$ is $1200 \mathrm{ng} / \mathrm{mL}$ for OPZ, $2000 \mathrm{ng} / \mathrm{mL}$ for PPZ, $1500 \mathrm{ng} / \mathrm{mL}$ for $\mathrm{LPZ}$ \\
and $700 \mathrm{ng} / \mathrm{mL}$ for RPZ, ${ }^{* * * H Q C}$ is $2200 \mathrm{ng} / \mathrm{mL}$ for OPZ, $3500 \mathrm{ng} / \mathrm{mL}$ for PPZ, $2500 \mathrm{ng} / \mathrm{mL}$ for LPZ and 1200 \\
ng/mL for RPZ
\end{tabular}


Table 4. Stability of the samples $(\mathrm{n}=6)$

\begin{tabular}{|c|c|c|c|c|c|c|c|c|c|c|c|c|c|}
\hline \multirow[b]{2}{*}{ Stability } & \multirow[b]{2}{*}{$\begin{array}{c}\text { Sample } \\
\text { concentratio } \\
\mathrm{n}(\mathrm{ng} / \mathrm{mL})\end{array}$} & \multicolumn{4}{|c|}{ OPZ PPZ } & \multicolumn{5}{|c|}{ LPZ } & \multicolumn{3}{|c|}{ RPZ } \\
\hline & & $\begin{array}{c}\text { Concentratio } \\
\text { n found } \\
(\mathrm{ng} / \mathrm{mL})\end{array}$ & $\mathrm{CV} \%$ & error $\%$ & $\begin{array}{l}\text { Concentrati } \\
\text { on found } \\
(\mathrm{ng} / \mathrm{mL})\end{array}$ & $\mathrm{CV} \%$ & $\begin{array}{l}\text { error } \\
\%\end{array}$ & $\begin{array}{l}\text { Concentration } \\
\text { found } \\
(\mathrm{ng} / \mathrm{mL})\end{array}$ & $\mathrm{CV} \%$ & $\begin{array}{c}\text { error } \\
\%\end{array}$ & $\begin{array}{l}\text { Concentration } \\
\text { found } \\
(\mathrm{ng} / \mathrm{mL})\end{array}$ & $\mathrm{CV} \%$ & $\begin{array}{c}\text { error } \\
\%\end{array}$ \\
\hline \multirow{2}{*}{$\begin{array}{l}\text { Short term } \\
\text { stability for } 12 \mathrm{~h} \\
\text { in plasma }\end{array}$} & LQC* & 60.4 & 2.15 & 0.67 & 61.7 & 3.40 & 2.83 & 59.8 & 2.01 & -0.33 & 61.8 & 5.66 & 3.00 \\
\hline & $\mathrm{HQC}^{* *}$ & 2253 & 1.11 & 2.41 & 3602 & 2.03 & 2.91 & 2660 & 2.29 & 6.40 & 1180 & 4.55 & -1.67 \\
\hline \multirow{2}{*}{$\begin{array}{l}\text { Three freeze and } \\
\text { thaw cycles }\end{array}$} & LQC* & 59.6 & 2.35 & -0.67 & 58.9 & 2.04 & -1.83 & 59.6 & 3.52 & -0.67 & 59.2 & 5.41 & -1.33 \\
\hline & $\mathrm{HQC}^{* *}$ & 2129 & 1.74 & -3.23 & 3457 & 2.49 & -1.23 & 2417 & 2.11 & -3.32 & 1103 & 4.55 & -8.08 \\
\hline \multirow{2}{*}{$\begin{array}{l}3 \text { months stability } \\
\text { at }<-80^{\circ} \mathrm{C}\end{array}$} & LQC* & 54.1 & 4.62 & -9.83 & 54.6 & 6.41 & -9.00 & 55.7 & 3.77 & -7.17 & 54.8 & 5.11 & -8.67 \\
\hline & $\mathrm{HQC}^{* *}$ & 2090 & 3.01 & -5.00 & 3398 & 2.39 & -2.91 & 2251 & 2.22 & -9.96 & 1091 & 5.51 & -9.08 \\
\hline
\end{tabular}

Table 5. Pharmacokinetic parameters of OPZ, PPZ, LPZ and RPZ after oral administration of $20 \mathrm{mg}$ OPZ, $20 \mathrm{mg}$ PPZ, $30 \mathrm{mg}$ LPZ or $20 \mathrm{mg}$ RPZ.

\begin{tabular}{|c|c|c|c|c|}
\hline Parameters & $\begin{array}{c}\text { OPZ } 20 \mathrm{mg} \\
(\mathrm{n}=8)\end{array}$ & $\begin{array}{c}\text { PPZ } 20 \mathrm{mg} \\
(\mathrm{n}=8)\end{array}$ & $\begin{array}{c}\text { LPZ } 30 \text { mg } \\
(n=8)\end{array}$ & $\begin{array}{c}\text { RPZ } 20 \mathrm{mg} \\
(\mathrm{n}=6)\end{array}$ \\
\hline $\mathrm{T}_{\max }(\mathrm{h})$ & $2.00 \pm 1.03$ & $2.35 \pm 0.28$ & $1.65 \pm 0.71$ & $1.25 \pm 0.35$ \\
\hline $\mathrm{C}_{\max }(\mathrm{ng} / \mathrm{mL})$ & $401 \pm 179$ & $889 \pm 407$ & $1132 \pm 340$ & $252 \pm 35$ \\
\hline $\operatorname{AUC}_{0-\infty}(\mathrm{ng} \mathrm{h} / \mathrm{mL})$ & $1094 \pm 439$ & $2369 \pm 1619$ & $2326 \pm 1153$ & $575 \pm 91$ \\
\hline
\end{tabular}


Gonzalez et al. achieved a simultaneous determination of OPZ and its two metabolites by using a standard ODS $\mathrm{C}_{18}$ column with the mobile phase of $\mathrm{pH} 8.0$ containing $0.015 \%$ nonylamine, and this prolonged the life of the column for analysis. However, the quantification limit (60 $\mathrm{ng} / \mathrm{mL}$ ) of OPZ in that method is not sufficiently sensitive to obtain precise pharmacokinetic parameters (5).

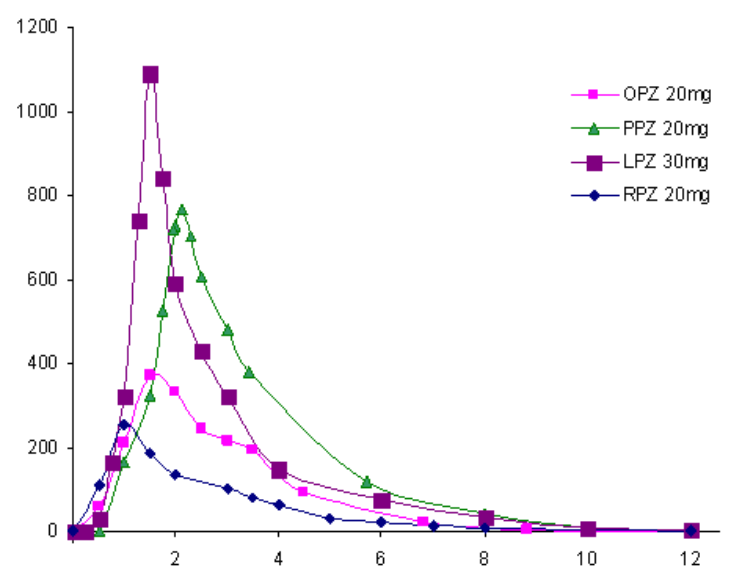

Figure 6. Mean plasma concentration vs time profile for each PPI following oral dosing to human subjects.

However, we were able to overcome this limitation using mobile phase of $\mathrm{pH} 7.3$ permitting stability of PPIs during analysis and use of TRACER EXCEL 120 ODS-A column which is less expensive than polymer based column.

Some previous methods used internal standards which are difficult to obtain commercially $(7-9,16$, 24). In this study a PPI was used as IS in the assay of other drugs in this class. Generally, large interindividual variations were observed in the pharmacokinetics of OPZ, PPZ and LPZ (2). Therefore, a more sensitive method having a wider range of capability is required for evaluating the precise pharmacokinetics of these drugs. The calibration curves obtained for each drug were linear over a wide range of concentrations (Table 1). It seems more likely the ranges of concentrations were used for selected PPIs cover the majority of PPIs concentrations usually obtained in clinic.

For studies that large numbers of samples are to be processed, solid phase extraction still remains as expensive alternative. The extraction procedure was used in this work yielded good recovery as well as high repeatability for all compounds (Table 3, 4). These two requisites are of great importance when an analytic method needs to be validated for providing reliable data. Both precision and accuracy at the LLOQ, low, medium and high concentrations of OPZ, PPZ, LPZ and RPZ in plasma were within acceptable limits for bioanalytical method (31). In the present study, we applied our method to determination of serum concentrations of OPZ, PPZ, LPZ and RPZ in a single oral dose. Pharmacokinetic parameters obtained in our study showed similar results reported officially.

\section{CONCLUSIONS}

In conclusion, we have developed and validated a rapid, simple and reproducible HPLC-UV method to determine plasma levels of four PPIs, i.e. OPZ, PPZ, LPZ and RPZ in human plasma. Considering the fact that the present method involves a shorter running time, simple operations and use of PPIs as IS for assay of other drugs in this class, it may be used in similar studies as a time and cost effective alternative to other available methods. This method is suitable for pharmacokinetic studies.

\section{ACKNOWLEDGMENTS}

This work was supported by a grant from Iran University of Medical Sciences (Grant No: 527).

\section{ABBREVIATIONS}

HQC: high quality control, IS: internal standard, LPZ: lansoprazole, LQC: low quality control, LLOQ: lower limit of quantification, MQC: middle quality control, OPZ: omeprazole, PPIs: proton pump inhibitors, PPZ: pantoprazole, QC: quality control, RPZ: rabeprazole, SD: standard deviation.

\section{REFERENCES}

1. Sachs G, Shin JM, Howden CW. Review article: the clinical pharmacology of proton pump inhibitors. Aliment Pharmacol Ther, 2006; 23:2-8.

2. Gardiner SJ, Begg EJ. Pharmacogenetics, drugmetabolizing enzymes, and clinical practice. Pharmacol Rev, 2006; 58:521-90. 
3. Amantea MA, Narang PK. Improved procedure for quantitation of omeprazole and metabolites using reversed-phase high-performance liquid chromatography. J Chromatogr, 1988; 426:216-22.

4. Garcia-Encina G, Farran R, Puig S, Martinez L. Validation of an automated liquid chromatographic method for omeprazole in human plasma using online solid-phase extraction. J Pharm Biomed Anal, $1999 ; 21: 371-82$.

5. Gonzalez HM, Romero EM, Chavez TdeJ, Peregrina AA, Quezada V, Hoyo-Vadillo C. Phenotype of CYP2C19 and CYP3A4 by determination of omeprazole and its two main metabolites in plasma using liquid chromatography with liquid-liquid extraction. J Chromatogr B Analyt Technol Biomed Life Sci, 2002; 780:459465.

6. Kobayashi K, Chiba K, Sohn DR, Kato Y, Ishizaki T. Simultaneous determination of omeprazole and its metabolites in plasma and urine by reversedphase high-performance liquid chromatography with an alkaline-resistant polymer-coated $\mathrm{C} 18$ column. J Chromatogr, 1992; 579:299-305.

7. Lagerstrom PO, Persson BA. Determination of omeprazole and metabolites in plasma and urine by liquid chromatography. J Chromatogr, 1984; 309:347-56.

8. Macek J, Ptacek P, Klima J. Determination of omeprazole in human plasma by high-performance liquid chromatography. J Chromatogr B Biomed Sci Appl, 1997; 689:239-43.

9. Mihaly GW, Prichard PJ, Smallwood RA, Yeomans ND, Louis WJ. Simultaneous highperformance liquid chromatographic analysis of omeprazole and its sulphone and sulphide metabolites in human plasma and urine. J Chromatogr, 1983; 278:311-9.

10. Motevalian M, Saeedi G, Keyhanfar F, Tayebi L, Mahmoudian M. Simultaneous determination of omeprazole and its metabolites in human plasma by HPLC using solid-phase extraction. pharm pharmacol comun, 1999; 5:265-268.

11. Prasad NV T, Steven L B. High Performance Liquid Chromatographic Method for the Analysis of Omeprazole and 5-Hydroxyomeprazole in Human Plasma. Analytical Letters, 1999; 32:22852295.

12. Rambla-Alegre M, Esteve-Romero J, Carda-Broch S. Analysis of omeprazole and its main metabolites by liquid chromatography using hybrid micellar mobile phases. Anal Chim Acta, 2009; 633:250-6.

13. Rezk NL, Brown KC, Kashuba AD. A simple and sensitive bioanalytical assay for simultaneous determination of omeprazole and its three major metabolites in human blood plasma using RPHPLC after a simple liquid-liquid extraction procedure. J Chromatogr B Analyt Technol Biomed Life Sci, 2006; 844:314-21.

14. Shimizu M, Uno T, Niioka T, Yaui-Furukori N, Takahata T, Sugawara K, Tateishi T. Sensitive determination of omeprazole and its two main metabolites in human plasma by column-switching high-performance liquid chromatography: application to pharmacokinetic study in relation to CYP2C19 genotypes. J Chromatogr B Analyt Technol Biomed Life Sci, 2006; 832:241-8.

15. Yim DS, Jeong JE, Park JY. Assay of omeprazole and omeprazole sulfone by semi-microcolumn liquid chromatography with mixed-function precolumn. J Chromatogr B Biomed Sci Appl, 2001; 754:487-93.

16. Yuen KH, Choy WP, Tan HY, Wong JW, Yap SP. Improved high performance liquid chromatographic analysis of omeprazole in human plasma. J Pharm Biomed Anal, 2001; 24:715-9.

17. Zarghi A, Foroutan SM, Shafaati A, Khoddam A. HPLC determination of omeprazole in human plasma using a monolithic column. Arzneimittelforschung, 2006; 56:382-6.

18. Kang WK, Kim DS, Kwon KI. Advanced method for determination of omeprazole in plasma by HPLC. Arch Pharm Res, 1999; 22:86-8.

19. Aoki I, Okumura M, Yashiki T. High-performance liquid chromatographic determination of lansoprazole and its metabolites in human serum and urine. J Chromatogr, 1991; 571:283-90.

20. Huber R, Muller W, Banks MC, Rogers SJ, Norwood PC, Doyle E. High-performance liquid chromatographic determination of the $\mathrm{H}+/ \mathrm{K}+$ ATPase inhibitor (BY 1023/SK\&F 96,022) and its sulphone metabolite in serum or plasma by direct injection and fully automated pre-column sample clean-up. J Chromatogr, 1990; 529:389-401.

21. Karol MD, Granneman GR, Alexander K. Determination of lansoprazole and five metabolites in plasma by high-performance liquid chromatography. J Chromatogr B Biomed Appl, 1995; 668:182-6.

22. Landes BD, Miscoria G, Flouvat B. Determination of lansoprazole and its metabolites in plasma by high-performance liquid chromatography using a loop column. J Chromatogr, 1992; 577:117-22.

23. Ramakrishna NV, Vishwottam KN, Wishu S, Koteshwara M. High-performance liquid chromatography method for the quantification of pantoprazole in human plasma. J Chromatogr B Analyt Technol Biomed Life Sci, 2005; 822:326-9.

24. Uno T, Yasui-Furukori N, Shimizu M, Sugawara $\mathrm{K}$, Tateishi T. Determination of rabeprazole and its active metabolite, rabeprazole thioether in human plasma by column-switching high-performance liquid chromatography and its application to 
pharmacokinetic study. J Chromatogr B Analyt Technol Biomed Life Sci, 2005; 824:238-43.

25. Zarghi A, Shafaati A, Foroutan SM, Movahed H, Khoddam A. A rapid high-performance liquid chromatographic method for the determination of pantoprazole in plasma using UV detection. Application in pharmacokinetic studies. Arzneimittelforschung, 2008; 58:441-4.

26. Park CW, Rhee YS, Go BW, Kam SH, Lee KH, Lee HS, Park ES. High performance liquid chromatographic analysis of rabeprazole in human plasma and its pharmacokinetic application. Arch Pharm Res, 2008; 31:1195-9.

27. Singh SS, Jain M, Shah H, Gupta S, Thakker P, Shah R, Lohray BB. Direct injection, column switching-liquid chromatographic technique for the estimation of rabeprazole in bioequivalence study. J Chromatogr B Analyt Technol Biomed Life Sci, 2004; 813:247-54.

28. Uno T, Yasui-Furukori N, Takahata T, Sugawara
$\mathrm{K}$, Tateishi T. Determination of lansoprazole and two of its metabolites by liquid-liquid extraction and automated column-switching highperformance liquid chromatography: application to measuring CYP2C19 activity. J Chromatogr B Analyt Technol Biomed Life Sci, 2005; 816:30914.

29. Hishinuma T, Suzuki K, Yamaguchi H, Yamagishi H, Koike T, Ohara S, Shimosegawa T, Mano N, Goto J. Simple quantification of lansoprazole and rabeprazole concentrations in human serum by liquid chromatography/tandem mass spectrometry. J Chromatogr B Analyt Technol Biomed Life Sci, 2008; 870:38-45.

30. Gupta HP, Saini K, Dhingra P, Pandey R. Study of Acid Catalyzed Reactions of Proton Pump Inhibitors at D.M.E. Portugaliae Electrochimica Acta, 2008; 26(5):433-448.

31. Shah VP, Midha KK, Findlay John WA, et al. Bioanalytical Method Validation-A Revisit with a Decade of Progress. Pharmaceutical Research, 2000; 17:1551-1557. 